\title{
Assess the Application Level of Hotels Located in Aqaba City to the ENAT Standards from the Staff's Point of View
}

\author{
Ibrahim Bazazo ${ }^{1}$, Mohammed Abdullah Nasseef ${ }^{2}$, Omar Al-Nsour $^{1}$, Sara Altheeb ${ }^{1} \&$ Hameed Abu Alez ${ }^{3}$ \\ ${ }^{1}$ Department of Tourism Management, Faculty of Tourism and Hospitality, The University of Jordan, Aqaba, Jordan \\ 2 Department of Business Administration, Faculty of Economics and Administration, King Abdulaziz University, \\ Jeddah, Saudi Arabia \\ ${ }^{3}$ Faculty of Tourism and Hospitality Management, The University of Jordan, Aqaba, Jordan \\ Correspondence: Ibrahim Bazazo, Department of Tourism Management, Faculty of Tourism and Hospitality, The \\ University of Jordan, Aqaba, Jordan. Tel: 962-3-209-0450. E-mail: i.bazazo@ju.edu.jo
}

Received: June 15, 2017

doi:10.5430/jms.v8n3p35
Accepted: June 22, 2017

Online Published: June 27, 2017

\begin{abstract}
The aim of this research is to explore the degree to which Aqaba city hotels apply ENAT (European Network for Accessible Tourism) standards towards disabled tourists. These include physical accessibility/outside areas, physical accessibility/internal access routes, toilet and bathroom, staff and additional services, and equipment for accessible venues. A total of 142 questionnaire containing 32 items was used to collect information from employees work in three, four, and five star hotels. Results of the current study revealed that the researched hotels apply ENAT standards to a great extent except for equipment for accessible venues. This study shall provide important feedback to hoteliers' decision-makers who are significant factors that can enhance the disability's services and put the hotel industry in Aqaba city at a competitive edge.
\end{abstract}

Keywords: ENAT standards, hotels, Aqaba, Jordan

\section{Introduction}

Travel and tourism has become the world's largest and fastest growing industry, and its growth shows a consistent year to year increase. Countries are increasingly developing tourism as part of their national development strategies as an effective driver of economic growth and inclusive development, creating jobs and wellbeing for communities (UNWTO, 2013). Tourism is considered not only as a basic human right and should be accessible to all, as recognized by many governments and supra-national organizations, but also as a tool to promote social inclusion. Although persons with a disability hold the same tourism desires and needs as other social groups, they are often excluded from leisure activities mainly due to several barriers and constraints (Figueiredo et al., 2012). Sang Yau et al. (2004) argued that living with a disability poses unique challenges and can influence participation in many activities. Tourism is one activity that many people with disabilities feel must be sacrificed as it requires an orchestrated cooperation of physical, mental, and social capabilities, which are often adversely affected or compromised by a disability. Ten percent of the worldwide population consists of people with disabilities. Persons with disabilities includes people with intellectual disabilities, physical, sensory (hearing, vision and speech), psychiatric or mental illness. Women who are pregnant, people with permanent and temporary injuries, people with small children and people who suffer from obesity also categorized as disabled. People with disabilities are often marginalized from the social environment. They tend to be older, poorer, less educated and has fewer employment opportunities than those without disabilities (Sanmargaraja \& Ta Wee, 2013).

In addition to this data, a rapid ageing of the population is under way. In 2009 there were more than 730 million people over age 60 , equivalent to $10 \%$ of the population7, an increase of more than $20 \%$ since an increase of more than $20 \%$ since 2000 , and age 60 will increase to account for $20 \%$ of the world population, with one-fifth of this group being over 80 years old (UNWTO, 2013). This shows the increase in the number of people with disabilities and increasing interest in this market and their requirements. Travelers with special needs have several requirements may make it difficult for them to move, and increase the complexity they have when they are not responding to their needs has been faced with difficult situations because of their disabilities. Many people with disability can cite a 
plethora of examples of discrimination caused by negligent or unsuitable design or service provision. In the built environment, wheelchair users are frequently excluded by environmental barriers put in at the design stage: at railway platforms without lifts; at entrances to banks and businesses with revolving doors; and on pavements without dropped kerbs (Darcy \& Dickson, 2009; Michopoulou et al., 2015). Also, several researchers consider the information systems and in particular the information technology (IT) and its flexibility as an enabler to achieve the desired competitive advantages, and as a crucial support to operational and strategic business decisions (Al Azmi et al., 2012; Alenezi et al., 2015; Alkalha et al., 2012; Almajali \& Tarhini, 2016; Altamony et al., 2012; Kateb et al., 2015; Maqableh \& Karajeh, 2014a, 2014b; Masa'deh, 2012, 2013a, 2013b; Masa'deh et al., 2016; Obeidat et al., 2013; Shannak et al., 2010, 2012a, 2012b; Tarhini et al., 2016; Vratskikh et al., 2016); thus further research is required to examine the role of such IT applications in enhancing the managerial decisions regarding disability services. In addition, scholars (e.g. Masa'deh et al. 2008; Hunaiti et al., 2009; Masa'deh \& Kuk, 2009; Alshurideh et al., 2012; Hajir et al., 2015; Kannan \& Gharibeh, 2013; Masa'deh \& Shannak, 2012; Masa'deh et al. 2013; Masa'deh et al. 2015a, 2015b, 2015c; Masa'deh et al. 2017; Obeidat et al., 2012, 2016; Shannak \& Alkour, 2012; Tarhini et al., 2015a, 2015b) emphasize the need for large firms to integrate their IT systems with their KM strategies and processes in order to survive in their highly competitive business environments, which in turn could accelerate the managerial decisions as well.

Tourism for disabled in Jordan is the newly product that did not come down after what it deserves as a producer growing globally increases the integrated selection of tourism in Jordan to fit in with what is owned by the Jordan of material and human resources, and therefore must be given to the disabled and the development of services necessary for them and facilities to attract more members of this category where this will bring a diversity of tourism product, and adds to the Jordan pattern new tourism compete globally. Jordan is at the forefront of the world in the interest handicapped healthy and credit is due to the attention of His Majesty King Abdullah II bin Al Hussein, may God protect him and Prince Raad bin Zaid Chief Secretary attention the disabled and improve their circumstances. Aqaba area is full of tourists who come to enjoy the magnificent sea and the atmosphere is nice. Aqaba considers the most important projects interested in eco-tourism in Jordan namely Aqaba station to monitor the birds, which attracts tens of thousands and perhaps millions of migratory birds during their journey between Europe and Africa during the seasonal migration in the fall and spring, which is the only seaport of Jordan so virtually most of Jordan's exports depart from this the city, and is the only station tourist cruise, making Aqaba superior to the rest of the governorates of Jordan.

This research aims to understand the importance of the Jordanian tourism sector in terms of contribution to the Jordanian economy and the fact that people with special needs is a growing market in the world, and should increase the Jordan market share in this category. This is by following the ENAT (European Network for Accessible Tourism) standards towards disabled tourists; to make tourism available and accessible to all people regardless of a deficit or not from one country to another, or travel within the country or any site a tourist attraction to have a desire to visit it; and to overview attitude towards disabilities and the importance of accessibilities in the context of people with disabilities and develop a tourism sector model by measuring relevant existing literature review.

\section{Literature Review}

Ozturk et al. (2008) conducted a research in order to assess the ability of the Turkish tourism industry to meet the requirements of people with disabilities in the tourism sector and travel agencies. Through a survey of the views of hotel managers and travel agencies in Turkey. In order to achieve the objectives of this study were conducted survey on hotels and travel agency The data were analyzed statistically using frequencies and percentages and average. Upon completion of the analysis and developed a number of conclusions: First, the Turkish tourism although it's new in this area, but it is ready to participate in this market. Second, in spite of the existence of weaknesses in some areas, but will have the ability to meet the needs of people with disabilities through improvements and the development of infrastructure and superstructure. However, Zhang \& Tian Cole (2016) provided a strategic order for lodging businesses to implement/improve service attributes so that they can maximize the satisfaction of customers with mobility challenges despite the possible limits of budgets or resources such as tracking system recording customers' special needs and accommodations, blocking of the accessible rooms and parking spots for people who indeed need them, and staff assignments to assist people with mobility challenges at the entrance for parking, entering, and checking-in procedures.

Michopoulou \& Buhalis (2013) aimed to explore the information provision requirements for the accessibility requiring market. Also, prompted the further investigation of these issues, and it focused on some of the research objectives have evolved followed: the veto or absolutely minimal prerequisites principle; an indication of holistic 
accessibility paths; and door-to-door access maps. The paper concludes by demonstrating how the tourism industry can overcome these challenges and address disabled travelers' needs. Darcy (2010) presented the way that accessible accommodation information is documented and marketed. Darcy presented the results of a survey to determine the relative importance of the criteria for selecting the room through the development of 55 -item scale access Hotel. Four information formats were then presented to achieve the preferences of the respondents. The results suggested that while socio-demographic variables offered some insight into criteria selection, the most significant explanation for criteria selection and information preferences were the dimensions of disability and level of support needs, focused to learn if the infrastructure of the hotels is adapted to this market segment (people with disabilities) because the aging population is a growing phenomenon worldwide and it leads to the shaping of a new market segment, through analyzing the opinions of these hotel managers opinions to know external barriers related to the development of tourism of people with disabilities in Romania (Mihaela, 2012). As a consequence author's strongly criticized that issues and reviewed booming tourism places in Bangladesh like Coxbazar which is well recognize and longest sea beach in the world. As outcomes there is no minimum opportunity for the-disabled travelers included 5 and 7 star hotels in Coxbazar (Coxbazar accommodation index). Popiel (2014) aimed to generate relevant knowledge about the travel needs and barriers of people with disabilities, to assess the current level of accessibility in the tourism sector especially in accommodation options, museums, offering services it was carried out based on literature review and a questionnaire and interviews with disability tourists.

The European Network for Accessible Tourism aims to help tourism providers to meet these demands. ENAT is a new network for travel and tourism businesses and organizations that support making tourism accessible to all customers in Europe. The Network aims to build bridges between travel and tourism businesses operating, specialist advisors, policy-makers, researchers, tourism education institutions, consumer organizations and Non-Governmental Organizations' in Europe; and also it aims to assist in the work of good design and accessible buildings cannot deliver truly accessible tourist experiences on their own. It is therefore vital that tourism providers develop and improve their services. Therefore, they are interested in tourists with disabilities and to focus on providing the best service and to encourage workers in the tourism sector to provide the best service for them (Vos et al., 2007). Small \& Morgan (2010) given an experimental example a tourist who is a wheelchair user and he is not able to access all public areas of Sydney Opera House in Australia. The person who is unable to access all public areas because of the building were constructed without lifts, ramps and also the building were not considered socially necessary needs.

Packer et al. (2007) aimed to explore and described the complex issues and factors related to participation in tourism as perceived by people with disabilities and the outcome of the study is the travel active emerged as a six-stage process, intricately related to the personal disability context and the environmental travel context. Personal and environmental factors contribute to the six-stage model to explaining the complex interplay between tourism, disability and environmental context, and the logistics of planning booking, preparing to set out and experience destinations and attractions requires great patience, dedication, and cost, usually more so than for those without disabilities. Barriers faced by travelers with disabilities (Smith, 1987; McKercher et al., 2002; Packer et al., 2007) include the following:

- Intrinsic barriers resulting primarily from an individual's own level of cognitive, physical, and psychological function that may be exacerbated by lack of knowledge and confidence.

- Economic barriers including the overall affordability of travel due to additional expenses for people with disabilities such as buying or hiring extra equipment, and a possible requirement for personalized assistance, transportation or accommodation.

- Environmental barriers such as inaccessible buildings and transport services; lack of safe access and difficulties resulting from inadequate or inappropriate signage or lighting.

- Interactive barriers such as availability and accuracy of information; lack of encouragement to participate or negative attitudes from people encountered.

According to Das \& Rudra (2015), they defined the Physical Disabilities as: some people with disability have mobility problem by born use a wheelchair, or crutches. In this contrast tourism industries may need to train up staffs to assist physical impairments person as a personal care. For that reason, ppeople with extensive access needs often need a personal assistant to help them with activities such as washing, clothing, eating, transport, etc. On the other hand, if this service is provided by their holiday accommodation, they can relax and enjoy their holiday together with their friend or partner (Vos et al., 2007). Therefore, due to the building environment in construction may or may not be made for the disabled persons so that many of the issues are affected for disabled impairments. As a result, upper level of authority in tourism industries should aware and concern to regards before taking any initiatives such as 
minimum space of disable toilet and shower, easy access in the any entrance era, and open access for wheelchair users and pushchairs prams, free access in lift and transporting, Das \& Rudra (2015). Eleven million people with physical disabilities are a significant potential market of China's tourism industry, especially when traveling companions are included. People with a physical disability rarely traveled alone (Darcy, 1998; Burnett \& Baker, 2001; Yuhua, 2006).

The current study was to complete what the researchers suggested in the development of tourism with the pattern of disability and by focusing on the city of Aqaba, which is considered the head of tourism in Jordan; so the current study focused on the utilization of the means and methods of statistical and scientific methodology used by researchers in previous studies in order to develop an overall picture the reality of tourism with disabilities in Aqaba.

\section{Research Methodology}

This section provides the methodology applied in the current study. It consists of the research operational definitions of the study's variables, besides data collection tool and research population and sample.

\subsection{Research Operational Definitions}

The current research considers five standards adapted from ENAT. These includes physical accessibility/outside areas, physical accessibility/internal access routes, toilet and bathroom, staff and additional services, and equipment for accessible venues; which were measured in the research questionnaire through six, seven, seven, four, and eight items respectively.

\subsection{Research Hypotheses}

The study is hypothesized as follows:

H1: There is a significant difference among the ENAT standards that Aqaba city hotels apply towards disabled tourists due to gender.

$\mathrm{H} 2$ : There is a significant difference among the ENAT standards that Aqaba city hotels apply towards disabled tourists due to age.

H3: There is a significant difference among the ENAT standards that Aqaba city hotels apply towards disabled tourists due to educational level.

H4: There is a significant difference among the ENAT standards that Aqaba city hotels apply towards disabled tourists due to career level.

H5: There is a significant difference among the ENAT standards that Aqaba city hotels apply towards disabled tourists due to hotel rank.

\subsection{Population and Sampling}

The targeted population of this study consisted of all staff who are responsible of disability services in Aqaba city hotels located in Jordan, specifically hotels 5, 4 and 3 stars. Thus, a judgment sampling technique was conducted. A total of 142 questionnaires was returned and applicable for statistical analysis. Indeed, the primary data was collected through a drop-and-collect survey technique. The surveys were distributed to the targeted staff working in the hotels that agreed to participate in the study. The questionnaire consisted of two sections; the first section in questionnaire presents general personal information about a respondent, the gender, age, educational level, career level and ranking of the hotel. The second section includes questions to measure the ENAT standards based on their operational definitions.

\section{Data Analysis and Results}

In order to explore the degree to which Aqaba city hotels apply ENAT standards towards disabled tourists, in which the items for these standards have been measured using 3-points Likert scale that varies between not applied $=1$; $2=$ less applied; and applied $=3$; reliability and validity analyses were conducted, descriptive analysis was used to describe the characteristic of sample and the respondents to the questionnaires items.

\subsection{Validity and Reliability}

Validity and reliability are two important measures to determine the quality and usefulness of the primary data. Validity is about accuracy and whether the instrument measures what it is intended to measure while reliability is about precision; it is used to check the consistency and stability of the questionnaire. Indeed, the researchers depended on scales and items that were previously developed and used by ENAT with similar interest. Also a draft of the questionnaire was formulated, and then it was reviewed by four academic lecturers -who have a sufficient 
knowledge and experience in this scope- to insure that each item is measuring what is intended to be measured, and to avoid the ambiguity and complexity in the phrasing of questions. The reliability of the instrument was measured by the Cronbach's alpha coefficient. Further, some scholars (e.g. Bagozzi \& Yi, 1988; Creswell, 2009) suggested that the values of all indicators or dimensional scales should be above the recommended value of 0.60 . Table 1 represents the results of Cranach's alpha for the ENAT standards. Cronbach's alpha coefficients of all the tested variables are above 0.60 which suggesting the composite measure is reliable.

Table 1. The cronbach's alpha coefficients of study variables/standards

\begin{tabular}{lcc}
\hline Variables/ ENAT Standards & Number of items & Cronbach alpha \\
\hline Physical accessibility/outside areas & 6 & 0.825 \\
\hline Physical accessibility/internal access routes & 7 & 0.904 \\
\hline Toilet and bathroom & 7 & 0.828 \\
\hline Staff and additional services & 4 & 0.746 \\
\hline Equipment for accessible venues & 8 & 0.753 \\
\hline
\end{tabular}

\subsection{Respondents Demographic Profile}

As indicated in Table 2, the demographic profile of the respondents for this study showed that they are typically males, most of them between 18-30 years old, the majorities hold graduate degrees; and most of them works in 5 star hotels in the back offices.

Table 2. Description of the respondents' demographic profiles

\begin{tabular}{|c|c|c|c|}
\hline Category & Category & Frequency & Percentage \% \\
\hline \multirow[t]{3}{*}{ Gender } & Males & 86 & 60.6 \\
\hline & Females & 56 & 39.4 \\
\hline & Total & 142 & 100 \\
\hline \multirow[t]{5}{*}{ Age } & 18 years - less than 25 & 42 & 29.6 \\
\hline & 25 years - less than 30 & 50 & 35.2 \\
\hline & 30 years - less than 40 & 31 & 21.8 \\
\hline & More than 40 years old & 19 & 13.4 \\
\hline & Total & 142 & 100 \\
\hline \multirow[t]{5}{*}{ Educational level } & Grad school & 6 & 4.2 \\
\hline & High school & 34 & 23.9 \\
\hline & College degree & 37 & 26.1 \\
\hline & Graduate degree & 60 & 42.3 \\
\hline & Advanced graduate degree & 5 & 3.5 \\
\hline \multirow[t]{5}{*}{ Career level } & Top level management & 14 & 9.9 \\
\hline & Middle level management & 36 & 25.4 \\
\hline & Supervisors & 37 & 26.1 \\
\hline & Back offices & 55 & 38.7 \\
\hline & Total & 142 & 100 \\
\hline \multirow[t]{4}{*}{ Hotel rank } & 5 star & 82 & 57.7 \\
\hline & 4 star & 36 & 25.4 \\
\hline & 3 star & 24 & 16.9 \\
\hline & Total & 142 & 100 \\
\hline
\end{tabular}




\subsection{Descriptive Analysis}

In order to describe the responses and thus the attitude of the respondents toward each question they were asked in the survey, the mean and the standard deviation were estimated. While the mean shows the central tendency of the data, the standard deviation measures the dispersion which offers an index of the spread or variability in the data (Pallant, 2005; Sekaran \& Bougie, 2013). In other words, a small standard deviation for a set of values reveals that these values are clustered closely about the mean or located close to it; a large standard deviation indicates the opposite. The level of each item was determined by the following formula: (highest point in Likert scale - lowest point in Likert scale) / the number of the levels used $=(3-1) / 5=0.66$, where 1-1.66 reflected by "low", 1.67-2.33 reflected by "moderate", and 2.34-3 reflected by "high". Then the items were being ordered based on their means. Tables 3 and 4 show the results.

Table 3. Overall mean and standard deviation of the study's variables

\begin{tabular}{lcccc}
\hline Type of Variable/Standard & Mean & Standard Deviation & Level & Order \\
\hline Physical accessibility/outside areas & 2.48 & 0.50 & High & 3 \\
\hline Physical accessibility/internal access routes & 2.50 & 0.52 & High & 2 \\
\hline Toilet and bathroom & 2.40 & 0.49 & High & 4 \\
\hline Staff and additional services & 2.51 & 0.50 & High & 1 \\
\hline Equipment for accessible venues & 2.29 & 0.44 & Moderate & 5 \\
\hline
\end{tabular}

As presented in Table 3, data analysis results have shown that ENAT standards in Aqaba hotels are applied to a high level in which the range of the mean score is 2.29-2.51. Table 4 demonstrates the mean, standard deviation, level, and order scores for items for each variable/standard.

Table 4. Mean and standard deviation of the study's variables

\begin{tabular}{lcccc}
\hline Physical accessibility/outside areas & Mean & SD & Level & Order \\
\hline $\begin{array}{l}\text { The hotel that am working at has - Parking spaces clearly designated for } \\
\text { disabled persons }\end{array}$ & 2.33 & 0.76 & Moderate & 6 \\
\hline $\begin{array}{l}\text { The hotel that am working at has - Drop-off area for motor vehicle } \\
\text { passengers at or near the front entrance }\end{array}$ & 2.41 & 0.72 & High & 5 \\
\hline $\begin{array}{l}\text { The hotel that am working at has - Access routes that are flat (without } \\
\text { steps) and with a stable surface }\end{array}$ & 2.62 & 0.62 & High & 1 \\
\hline $\begin{array}{l}\text { The hotel that am working at has - Ramps as alternative routes to steps and } \\
\text { handrails where necessary }\end{array}$ & 2.42 & 0.68 & High & 4 \\
\hline $\begin{array}{l}\text { The hotel that am working at has - Entrance doors with level access, } \\
\text { sheltered from rain and well lit }\end{array}$ & 2.58 & 0.62 & High & 2 \\
\hline $\begin{array}{l}\text { The hotel that am working at has - Tactile and high-contrast route } \\
\text { markings in the outside areas }\end{array}$ & 2.52 & 0.68 & High & 3 \\
\hline Physical accessibility/internal access routes & Mean & SD & Level & Order \\
\hline $\begin{array}{l}\text { The hotel that am working at has - Door handles - easy to reach and } \\
\text { operate, or automatic opening/closing }\end{array}$ & 2.48 & 0.69 & High & 5 \\
\hline $\begin{array}{l}\text { The hotel that am working at has - Wide doors, passageways, corridors and } \\
\text { space to pass between dining tables, display stands. }\end{array}$ & 2.56 & 0.62 & High & 1 \\
\hline $\begin{array}{l}\text { The hotel that am working at has - Clear turning spaces in rooms, meeting } \\
\text { rooms, entrance halls }\end{array}$ & 2.51 & 0.64 & High & 3 \\
\hline $\begin{array}{l}\text { The hotel that am working at has - Clear general signage and } \\
\text { understandable pictograms }\end{array}$ & 2.49 & 0.67 & High & 4 \\
\hline $\begin{array}{l}\text { Lifts (elevators) - wide and deep with tactile buttons; visual and audible } \\
\text { indication of floors }\end{array}$ & 2.44 & 0.70 & High & 6 \\
\hline
\end{tabular}




\begin{tabular}{|c|c|c|c|c|}
\hline $\begin{array}{l}\text { The hotel that am working at has - Signage indicating accessible areas and } \\
\text { features }\end{array}$ & 2.51 & 0.61 & High & 3 \\
\hline $\begin{array}{l}\text { The hotel that am working at has - Tactile and high-contrast route } \\
\text { markings in the inside areas }\end{array}$ & 2.55 & 0.61 & High & 2 \\
\hline Toilet and bathroom & Mean & SD & Level & Order \\
\hline $\begin{array}{l}\text { The hotel that am working at has - Support handrails beside toilets, baths } \\
\text { and overhead showers }\end{array}$ & 2.41 & 0.74 & High & 4 \\
\hline $\begin{array}{l}\text { The hotel that am working at has - Free space beside toilets for side } \\
\text { transfer }\end{array}$ & 2.42 & 0.65 & High & 3 \\
\hline $\begin{array}{l}\text { The hotel that am working at has - Wheel-in shower (no step) and non-slip } \\
\text { floor surfaces in bathrooms }\end{array}$ & 2.49 & 0.69 & High & 2 \\
\hline The hotel that am working at has - Toilet seat raisers (different sizes) & 2.37 & 0.71 & High & 5 \\
\hline $\begin{array}{l}\text { The hotel that am working at has - Shower chair or wall-mounted shower } \\
\text { seating }\end{array}$ & 2.15 & 0.79 & Moderate & 6 \\
\hline $\begin{array}{l}\text { The hotel that am working at has - Accessible toilets available in transit } \\
\text { responsible areas }\end{array}$ & 2.53 & 0.62 & High & 1 \\
\hline $\begin{array}{l}\text { The hotel that am working at has - Sufficient comfortable seating in transit } \\
\text { / waiting areas }\end{array}$ & 2.49 & 0.69 & High & 2 \\
\hline Staff and additional services & Mean & SD & Level & Order \\
\hline $\begin{array}{l}\text { The hotel that am working at has - Staff trained in disability awareness and } \\
\text { client-friendly service }\end{array}$ & 2.33 & 0.72 & Moderate & 3 \\
\hline $\begin{array}{l}\text { The hotel that am working at has - Catering - meals available for people } \\
\text { with allergies or special diets. }\end{array}$ & 2.60 & 0.59 & High & 1 \\
\hline $\begin{array}{l}\text { The hotel that am working at has - Smoke free areas and a smoke free } \\
\text { policy }\end{array}$ & 2.56 & 0.65 & High & 2 \\
\hline $\begin{array}{l}\text { The hotel that am working at has - Special Assistance' (available free of } \\
\text { charge) by well-trained staff (for boarding and disembarking, for retrieving } \\
\text { luggage) }\end{array}$ & 2.56 & 0.69 & High & 2 \\
\hline Equipment for accessible venues & Mean & SD & Level & Order \\
\hline The hotel that am working at has - Electric beds & 1.68 & 0.82 & Moderate & 7 \\
\hline $\begin{array}{l}\text { The hotel that am working at has - Remote controls for windows, lighting, } \\
\text { TV }\end{array}$ & 2.02 & 0.74 & Moderate & 5 \\
\hline $\begin{array}{l}\text { The hotel that am working at has - Flashing or vibrating alerts for } \\
\text { smoke/fire alarms, telephones, guestroom doors }\end{array}$ & 2.60 & 0.66 & High & 2 \\
\hline The hotel that am working at has - Manual wheelchairs & 2.37 & 0.77 & High & 4 \\
\hline The hotel that am working at has - Beach-wheelchairs & 1.89 & 0.84 & Moderate & 6 \\
\hline The hotel that am working at has - Cooling fan/ Fan heater & 2.63 & 0.65 & High & 1 \\
\hline The hotel that am working at has - Choice of hard/soft mattress & 2.63 & 0.62 & High & 1 \\
\hline $\begin{array}{l}\text { The hotel that am working at has - Wardrobe clothes with pull-down } \\
\text { coat-hangers and accessible }\end{array}$ & 2.52 & 0.64 & High & 3 \\
\hline
\end{tabular}

\subsection{Hypotheses Testing Results}

Hypotheses $\mathrm{H} 1, \mathrm{H} 2, \mathrm{H} 3, \mathrm{H} 4$ and $\mathrm{H} 5$ argued that there is a significant difference among the ENAT standards that Aqaba city hotels apply towards disabled tourists due to gender, age, educational level, career level, and hotel rank. Independent Samples T-test was employed in order to investigate if there any significant differences in the ENAT standards towards disabled tourists due to gender. Also, ANOVA tests were employed to examine the other four hypotheses, shown in Tables 6-9, noting the abbreviations as PO: Physical accessibility/outside areas; PI: Physical accessibility/internal access routes; TB: Toilet and bathroom; SA: Staff and additional services; and EA: Equipment for accessible venues. 
Table 5. T-test of differences among the ENAT standards that Aqaba city hotels apply towards disabled tourists due to gender

\begin{tabular}{lllllllll}
\hline & Gender & $\mathrm{N}$ & Mean & Std. Deviation & Std. Error Mean & $\mathrm{T}$ & $\mathrm{DF}$ & Sig \\
\hline \multirow{2}{*}{ PO } & Male & 86 & 2.5562 & .45202 & .04874 & 2.175 & 100.605 & 0.032 \\
\cline { 2 - 9 } & Female & 56 & 2.3631 & .55515 & .07418 & & & \\
\hline \multirow{2}{*}{ PI } & Male & 86 & 2.5714 & .50114 & .05404 & 1.873 & 111.745 & 0.064 \\
\cline { 2 - 9 } & Female & 56 & 2.4031 & .53737 & .07181 & & & \\
\hline \multirow{2}{*}{ TB } & Male & 86 & 2.4950 & .49278 & .05314 & 2.730 & 121.620 & 0.007 \\
\cline { 2 - 9 } & Female & 56 & 2.2704 & .47001 & .06281 & & & \\
\hline \multirow{2}{*}{ SA } & Male & 86 & 2.5494 & .48480 & .05228 & 1.120 & 110.169 & 0.235 \\
\cline { 2 - 9 } & Female & 56 & 2.4509 & .52962 & .07077 & & & \\
\hline \multirow{2}{*}{ EA } & Male & 86 & 2.3285 & .42489 & .04582 & 1.195 & 110.563 & 0.235 \\
\cline { 2 - 9 } & Female & 56 & 2.2366 & .46201 & .06174 & & & \\
\hline
\end{tabular}

Results of T-test, shown in Table 5, indicated that there is a significant among the ENAT standards that Aqaba city hotels apply towards disabled tourists can be attributed to gender for physical accessibility/outside areas, and toilet and bathroom; whereas no significant difference found for physical accessibility/internal access routes, staff and additional services, and equipment for accessible venues.

Table 6. ANOVA analysis of differences among the ENAT standards that Aqaba city hotels apply towards disabled tourists due to age

\begin{tabular}{llrrrrr}
\hline & Sum of Squares & df & Mean Square & \multicolumn{1}{l}{ F } & \multicolumn{1}{l}{ Sig. } \\
\hline \multirow{3}{*}{ PO } & Between Groups & 2.366 & 3 & .789 & 3.277 & .023 \\
& Within Groups & 33.216 & 138 & .241 & & \\
& Total & 35.582 & 141 & & & \\
& Between Groups & 5.164 & 3 & 1.721 & 7.192 & .000 \\
PI & Within Groups & 33.027 & 138 & .239 & & \\
& Total & 38.190 & 141 & & & \\
& Between Groups & 1.807 & 3 & .602 & 2.543 & .059 \\
TB & Within Groups & 32.695 & 138 & .237 & & \\
& Total & 34.502 & 141 & & & \\
& Between Groups & 1.216 & 3 & .405 & 1.621 & .187 \\
SA & Within Groups & 34.518 & 138 & .250 & & \\
& Total & 35.734 & 141 & & & \\
& Between Groups & .816 & 3 & .272 & 1.414 & \\
EA & Within Groups & 26.555 & 138 & .192 & & \\
& Total & 27.371 & 141 & & & \\
\hline
\end{tabular}

Table 6 indicated that there is a significant difference among two ENAT standards that Aqaba city hotels apply towards disabled tourists due to age (i.e. physical accessibility/outside areas, and physical accessibility/internal access routes); whereas no significant difference found for toilet and bathroom; staff and additional services; and equipment for accessible venues due to the moderator variable of age. 
Table 7. ANOVA analysis of differences among the ENAT standards that Aqaba city hotels apply towards disabled tourists due to educational level

\begin{tabular}{llrrrrr}
\hline & & Sum of Squares & df & Mean Square & F & \multicolumn{1}{l}{ Sig. } \\
\hline \multirow{3}{*}{ PO } & Between Groups & 1.542 & 4 & .386 & 1.552 & .191 \\
& Within Groups & 34.040 & 137 & .248 & & \\
& Total & 35.582 & 141 & & & \\
& Between Groups & 2.709 & 4 & .677 & 2.615 & .038 \\
PI & Within Groups & 35.481 & 137 & .259 & & \\
& Total & 38.190 & 141 & & & \\
& Between Groups & .910 & 4 & .228 & .928 & .450 \\
TB & Within Groups & 33.592 & 137 & .245 & & \\
& Total & 34.502 & 141 & & & \\
& Between Groups & 1.109 & 4 & .277 & 1.097 & .361 \\
SA & Within Groups & 34.625 & 137 & .253 & & \\
& Total & 35.734 & 141 & & & \\
& Between Groups & .463 & 4 & .116 & .590 & .671 \\
EA & Within Groups & 26.908 & 137 & .196 & & \\
& Total & 27.371 & 141 & & & \\
\hline
\end{tabular}

Table 7 showed that there is no significant difference among ENAT standards that Aqaba city hotels apply towards disabled tourists due to educational level except for physical accessibility/internal access routes.

Table 8. ANOVA analysis of differences among the ENAT standards that Aqaba city hotels apply towards disabled tourists due to career level

\begin{tabular}{llrrrrr}
\hline & Sum of Squares & df & Mean Square & F & \multicolumn{1}{l}{ Sig. } \\
\hline \multirow{2}{*}{ PO } & Between Groups & 1.489 & 3 & .496 & 2.009 & .116 \\
& Within Groups & 34.093 & 138 & .247 & & \\
& Total & 35.582 & 141 & & & \\
& Between Groups & 4.531 & 3 & 1.510 & 6.193 & .001 \\
PI & Within Groups & 33.659 & 138 & .244 & & \\
& Total & 38.190 & 141 & & & \\
& Between Groups & 2.698 & 3 & .899 & 3.903 & .010 \\
TB & Within Groups & 31.804 & 138 & .230 & & \\
& Total & 34.502 & 141 & & & \\
& Between Groups & 2.714 & 3 & .905 & 3.780 & .012 \\
SA & Within Groups & 33.020 & 138 & .239 & & \\
& Total & 35.734 & 141 & & & \\
& Between Groups & .904 & 3 & .301 & 1.571 & .199 \\
EA & Within Groups & 26.468 & 138 & .192 & & \\
& Total & 27.371 & 141 & & & \\
\hline
\end{tabular}

Table 8 indicated that there is a significant difference among three ENAT standards that Aqaba city hotels apply towards disabled tourists due to career level (i.e. physical accessibility/outside areas, physical accessibility/internal access routes, toilet and bathroom; whereas no significant difference found for physical accessibility/outside areas, and equipment for accessible venues due to the moderator variable of career level. 
Table 9. ANOVA analysis of differences among the ENAT standards that Aqaba city hotels apply towards disabled tourists due to hotel rank

\begin{tabular}{llrrrrr}
\hline & & Sum of Squares & df & Mean Square & F & \multicolumn{1}{l}{ Sig. } \\
\hline \multirow{3}{*}{ PO } & Between Groups & 2.278 & 2 & 1.139 & 4.753 & .010 \\
& Within Groups & 33.305 & 139 & .240 & & \\
& Total & 35.582 & 141 & & & \\
& Between Groups & 2.498 & 2 & 1.249 & 4.864 & .009 \\
PI & Within Groups & 35.692 & 139 & .257 & & \\
& Total & 38.190 & 141 & & & \\
& Between Groups & 4.961 & 2 & 2.480 & 11.671 & .000 \\
TB & Within Groups & 29.541 & 139 & .213 & & \\
& Total & 34.502 & 141 & & & \\
& Between Groups & .383 & 2 & .192 & .754 & .473 \\
SA & Within Groups & 35.351 & 139 & .254 & & \\
& Total & 35.734 & 141 & & & \\
& Between Groups & .423 & 2 & .212 & 1.092 & .338 \\
EA & Within Groups & 26.948 & 139 & .194 & & \\
& Total & 27.371 & 141 & & & \\
\hline
\end{tabular}

Table 9 showed that there is a significant difference among three ENAT standards that Aqaba city hotels apply towards disabled tourists due to hotel rank (i.e. physical accessibility/outside areas, and physical accessibility/internal access routes); whereas no significant difference found for staff and additional services, and equipment for accessible venues due to the moderator variable of hotel rank.

\section{Discussion and Conclusions}

Being the first survey in Aqaba to studying the facilities forwarded to people with disabilities in the hoes, the current research reveals the extent of offering services make it easier for people with physical disabilities in Aqaba hotels based on ENAT standard. Practically, this study provides a strategic order for lodging businesses to implement/improve service attributes so that they can maximize the satisfaction of customers with mobility challenges despite the possible limits of budgets or resources. Initially, a lodging business should prioritize the bottom-line delivery of service attributes which with negative performance can result in significant customer dissatisfaction (including the basic and performance factors); with more available investment resources, the lodging business should move on from avoiding customer dissatisfaction to maximizing customer satisfaction through the above-and-beyond service delivery, including the implementation of excitement factors and further improvement of performance factors.

In this study, the adapted ENAT approach classifies five elements-identified lodging service attributes into basic, performance, and excitement factors that contribute differently to customer satisfaction. The basic and performance factors that contribute significantly to customer dissatisfaction are proposed to be implemented as priorities. For the client market dealing with mobility challenges, failure to meet their bottom-line expectation about these factors may cause a business to be susceptible to lawsuits. The basic factors, including entrance accessibility, moving convenience, and information credibility, must meet the expected level of performance to avoid strong dissatisfaction from this market. There is no need to spend undue resources to over-perform on these service factors, however, as their over-performance would not result in a significant increase of overall satisfaction. Some simple (and not overly costly) tactics by lodging managers should be sufficient to address these basic factors, such as providing detailed and accurate accessibility information providence through websites and staff, a tracking system recording customers' special needs and accommodations, blocking of the accessible rooms and parking spots for people who indeed need them, and staff assignments to assist people with mobility challenges at the entrance for parking, entering, and checking-in procedures.

The five performance factors involving shower accessibility, room settings, staff attitude and capability, access to the room, and public area accessibility cause constant returns in overall satisfaction/ dissatisfaction. Given that these 
factors can also have significant influences over dissatisfaction, they should also be addressed as priorities that are similar to the basic factors. Once these attributes reach the bottom-line performance level that result in no customer dissatisfaction, the further improvements of these attributes can definitely significantly increase customer satisfaction. Yet further improvements should depend on the positioning and budgeting of a lodging business despite its wishes for every service dimension's optimum performance. Also, over half lodging businesses were found to perform satisfactorily on shower accessibility, staff attitude and capability, and room settings, yet only a minority performed well enough on access to the room and public area accessibility, which suggests some common deficiencies of performance factors that need to be addressed within the lodging industry. Some possible strategies that may fix this problem include: access to room, which can be improved by ensuring the functionality of elevators and securing ramp appliances to any existing steps on the way to/from the accessible guest rooms. Staff attitude and capability, on the other hand, needs the professional training of employees and managers to increase awareness of how to serve the population with mobility challenges. Specifically, respectfulness, patience, and responsiveness are the most expected/desired characteristics of staff when serving this population. Although most lodging businesses have initiated some level of employee training for serving this market, a large proportion of these trainings lack a standardized criteria and thus have not produced satisfactory outcomes (Kim \& Lehto, 2012).

Of the 142 respondents, more than half of the study respondents $86(60.6 \%)$ are males . A large majority of respondents $(35.2 \%)$ were between twenty five to thirty age, $(42.3 \%)$ respondents reported Graduate degree as their highest level of educational level. And most of them works in 5 star hotels $(57.7 \%)$ in the back offices (38.7\%). Results also showed this study is that most of the hotels are committed to the implementation of access roads that are flat (no steps) with a stable surface $2.62(0.62)$ because it does not need to be costly also considered one of the important aspects that make up a key factor in the creation of the hotel, and was less application in physical access/outside areas are Parking spaces clearly designated for disabled persons $2.33(0.76)$ this is because hotel owners and managers believed that people with physical disabilities do not move on their own, but the existence person facilities for them as a friend or a family member. While in the physical accessibility/internal access routes to reach the result was that most of the hotels are in the obligation to apply for the doors wide, passageways, corridors and space to pass between dining tables, display stands $2.56(0.62)$. However, they were not interested in the elevators (lifts) - wide and deep with tactile buttons; visual and audible indication of floors 2.44(0.70). Because of the lack of a previous design is interested in the services and facilities provided for people with physical disabilities and the non-existence of a variety of options lifts. Nevertheless, the results and found that the services provided in the bathrooms and toilets were lacking shower chair or wall-mounted shower seating $2.15(0.79)$. The reason could be due to the lack of these special shower chair, to the lack of the presence of people with expertise in the design and manufacture, and also being occupies space in the bathrooms and shower; while there is a good service in the accessible toilets available in transit responsible areas $2.53(0.62)$, as it is available as well an essential service in the areas of access, rest and reception.

The study also found that there is weakness in the training of staff in hotels and make them aware of how to deal with people with a disability $2.33(0.72)$, this is due to the lack of awareness of management and owners of hotels about how important this category of the tourist market and the lack of knowledge of their needs to achieve satisfaction and attract there, but there was a commitment in the food catering - Meals available for people with allergies or special diet $2.60(0.59)$ because it is generally found in all classified hotels chefs team with experience and the food is prepared at the customers' desire. For the equipment accessible places results indicated that there is a serious weakness in the electronic service beds $1.68(0.82)$ and wheelchairs for the beach $1.89(0.84)$ because of the high cost of this type of electronic beds and the inability of the hotels on the provided, and the lack of chairs for the beaches and facilitating ways to walk on them, also because of the high costs and lack of to interest of people with physical disabilities, but there were services provided are as good as cooling fan/ fan heater $2.63(0.65)$ and choice of hard/soft mattress 2.63(0.62) as they are essential services are available at all hotels and cannot be abandoned, as a basic need for all the regular customers, or for people with a disability.

The hospitality and tourism studies thereafter could apply this approach to each sub-lodging sector (resort, vacation apartment), or across other hospitality sectors (restaurants, attractions, transportation). Education and training on awareness and sensitivity to disability issues should be more in promoting tourism accessibility. Close collaboration between disabled organizations and tourism industry along with the education sector will facilitate the development of training programs required. Through training classes provided for the staff in the travel trade to learn how to care for the people with disabilities. In return, more business will come from satisfied customers with disabilities. In addition, the tourism industry needs to become more familiar with accessibility standards and the needs of tourists with disabilities. Accessibility audits performed by knowledge people with disabilities may be a key to the 
improvement of facilities and services. The facilities in terms of hotels, is a very important problem in carrying out tourism for the disabled people. Inappropriate environmental conditions, quality of architecture of hotels is another very important issue, areas such as entrances, car parks, halls and receptions are equipped group, while other areas of stairs, rooms and bathrooms, reception and toilets, most of the managers believe that this market has potential.

\section{References}

Abbasi, M. S., Elyas, T., \& Shah, F. (2015). Impact of individualism and collectivism over the individual's technology acceptance behaviour: A multi-group analysis between Pakistan and Turkey. Journal of Enterprise Information Management, 28(6), 747-768. https://doi.org/10.1108/JEIM-12-2014-0124

Al Azmi, N., Al-Lozi, M., Al-Zu’bi, Z., Dahiyat, S., \& Masa'deh, R. (2012). Patients Attitudes toward Service Quality and its Impact on their Satisfaction in Physical Therapy in KSA Hospitals. European Journal of Social Sciences, 34(2), 300-314.

Al-Badi, A., Tarhini, A., \& Al-Kaaf, W. (2017). Financial Incentives for Adopting Cloud Computing in Higher Educational Institutions. Asian Social Science, 13(4), 162-174. https://doi.org/10.5539/ass.v13n4p162

Al-Badi, A., Tarhini, A., \& Al-Sawaei, S. (2017). Utilizing Social Media to Encourage Domestic Tourism in Oman. International Journal of Business and Management, 12(4), 84-94. https://doi.org/10.5539/ijbm.v12n4p84

Al-Badi, A. H., \& Al-Qayoudhi, W. S. (2014). Adoption of social networks in business: Study of users and potential users in Oman. The International Business \& Economics Research Journal (Online), 13(2), 401-415.

Al-Dmour, H., Al-Madani, S., Alansari, I., \& Al-Dmour, R. (2016). Factors Affecting the Effectiveness of Cause-Related Marketing Campaign: Moderating Effect of Sponsor-Cause Congruence. International Journal of Marketing Studies, 8(5), 114-127. https://doi.org/10.5539/ijms.v8n5p114

Al-Dmour, R., \& Obeidat, B. (2015). Strategic IT-Business Alignment as Managers' Explorative and Ecploitative Strategies. European Scientific Journal, 11(7), 437-457.

Alenezi, H., Masa'deh, R. Alalwan, A., \& Al-Qirim, N. (2017). Factors Affecting e-Government Adoption in Kuwait: A Qualitative study. Electronic Journal of e-Government, 15(2), 84-102.

Alenezi, H., Tarhini, A., \& Masa'deh, R. (2015). Investigating the Strategic Relationship between Information Quality and E-Government Benefits: A Literature Review. International Review of Social Sciences and Humanities, 9(1), 33-50.

Alkalha, Z., Al-Zu'bi, Z., Al-Dmour, H., \& Alshurideh, M. (2012). Investigating the Effects of Human Resource Policies on Organizational Performance: An Empirical Study on Commercial Banks Operating in Jordan. European Journal of Economics, Finance and Administrative Sciences, 51, 44-64.

Allam, M., \& Elyas, T. (2016). Perceptions of Using Social Media as an ELT Tool among EFL Teachers in the Saudi Context. English Language Teaching, 9(7), 1-9. https://doi.org/10.5539/elt.v9n7p1

Almajali, D., \& Tarhini, A. (2016). Antecedents of ERP Systems Implementation Success: A Study on Jordanian Healthcare Sector. Journal of Enterprise Information Management, 29(4), 549-565.

Al-Mukhaini, E. M., Al-Qayoudhi, W. S., \& Al-Badi, A. H. (2014). Adoption of social networking in education: A study of the use of social networks by higher education students in Oman. Journal of International Education Research, 10(2), 143-155. https://doi.org/10.19030/jier.v10i2.8516

Alqahtani, M. A., Al-Badi, A. H., \& Mayhew, P. J. (2012). The Enablers and Disablers of E-Commerce: Consumers' Perspectives. The Electronic Journal of Information Systems in Developing Countries, 54(1), 1-25.

Al-Qirim, M., Rouibah, K., Serhani, M. A., Yammahi, A. R., \& Yammahi, M. A. (2017). Towards a Personality Understanding of Information Technology Students and their IT Learning in UAE University. Education and Information Technologies, 1-12. https://doi.org/10.1007/s10639-017-9578-1

Al-Qirim, N., Rouibah, K., Serhani, M. A., Yammahi, A. R., \& Yammahi, M. A. (2017). Learning Orientations of IT Higher Education Students in UAE University. Education and Information Technologies, 1-14. https://doi.org/10.1007/s10639-017-9589-y

Al-Qirim N., Tarhini, A., Rouibah, K. (2017). Determinants of Big Data Adoption and Success. Forthcoming in International Conference on Communications and Future Internet (ICCFI 2017). Jeju Island, South Korea, 10-13 August.

Alrowwad, A., Obeidat, B.Y., \& Aqqad, N. (2017). The impact of transformational leadership on organizational 
performance via the mediating role of corporate social responsibility: A structural equation modeling approach. International Business Research, 10(1), 199-221. https://doi.org/10.5539/ibr.v10n1p199

Alshurideh, M., Masa'deh, R., \& Alkurdi, B. (2012). The Effect of Customer Satisfaction on Customer Retention in the Jordanian Mobile Market: An Empirical Investigation. European Journal of Economics, Finance and Administrative Sciences, 47, 69-78.

Altamony, H., Alshurideh, M., \& Obeidat, B. (2012). Information Systems for Competitive Advantage: Implementation of an Organizational Strategic Management Process. Proceedings of the 18th IBIMA Conference on Innovation and Sustainable Economic Competitive Advantage: From Regional Development to World Economic, Istanbul, Turkey, 9th-10th May.

Altamony, H., Ali Akour, M., Gharaibeh, A., Al-Sati, Z. \& Elyas, T. (2016).The Relationship between Change Management Strategy and Successful Enterprise Resource Planning (ERP) Implementations: A Theoretical Perspective. International Journal of Business Management and Economic Research (IJBMER), 7(4), 690-703.

Bagozzi, R., \& Yi, Y. (1988). On the Evaluation of Structural Evaluation Models. Journal of the Academy of Marketing Science, 16(1), 74-94. https://doi.org/10.1007/BF02723327

Bisharat, H., Obeidat, B.Y., Alrowwad, A., Tarhini, A., \& Mukattash, I. (2017). The Effect of Human Resource Management Practices on Organizational Commitment in Chain Pharmacies in Jordan. International Journal of Business and Management, 12(1), 50-67. https://doi.org/10.5539/ijbm.v12n1p50

Burnett, J. J., \& Baker, H. B. (2001). Assessing the Travel-Related Behaviors of the Mobility-Disabled Consumer. Journal of Travel Research, 40(1). https://doi.org/10.1177/004728750104000102

Coxbazar Accommodation. Retrieved March 24, 2016, from http://coxsbazar-bd.com/index.php

Creswell, J. (2009). Research Design: Qualitative, Quantitative, and Mixed Methods Approaches (3rd ed.). Thousand Oaks: Sage Publications.

Darcy, S. (1998). Anxiety to Access: Tourism Patterns and Experiences of New South Wales People with a Physical Disability. Sydney, Australia: Tourism New South Wales.

Darcy, S. (2010). Inherent Complexity: Disability, Accessible Tourism and Accommodation Information Preferences. Tourism Management, 31(6), 816-826. ,

Darcy, S., \& Dickson, T. (2009). A whole-of-Life Approach to Tourism: The Case for Accessible Tourism Experiences. Journal of Hospitality and Tourism Management, 16(1), 32-44. https://doi.org/10.1375/jhtm.16.1.32

Das, S., \& Rudra, R. (2015). Tourism Accessibility for Disabled Travelers: An Optimistic Concept on Tourism Industry in Bangladesh. International Journal of Advancements in Research \& Technology, 4(10), 37-48.

El-Masri, M., \& Tarhini, A. (2015). A Design Science Approach to Gamify Education: From Games to Platforms. Twenty-Third European Conference on Information Systems (ECIS), Münster, Germany. 26-29 May 2015.

El-Masri, M., \& Tarhini, A. (2017). Factors affecting the adoption of e-learning systems in Qatar and USA: Extending the Unified Theory of Acceptance and Use of Technology 2 (UTAUT2). Educational Technology Research and Development, 65(3), 743-763. https://doi.org/10.1007/s11423-016-9508-8

El-Masri, M., Orozco, J., Tarhini, A., \& Tarhini, T. (2015). The Impact of IS-Business Alignment Practices on Organizational Choice of IS-Business Alignment Strategies. The 19th Pacific Asia Conference on Information Systems (PACIS 2015), Paper 215, Singapore, 6-9 July 2015.

Elyas, T., \& Picard, P. (2012).Teaching and Moral Tradition in Saudi Arabia: A Paradigm of Struggle or Pathway towards Globalization?. Procedia - Social and Behavioral Sciences, 41, 1083-1086. https://doi.org/10.1016/j.sbspro.2012.06.782

Fedai, L., Daglı, G., Altınay, Z., \& Altınay, F. (2017). The examination of occupational burnout and job satisfaction of the physical education teachers. International Journal of Economic Perspectives, 11(1), 12-26.

Figueiredo, E., Eusébio, C., \& Kastenholz, E. (2012). How Diverse are Tourists with Disabilities? A Pilot Study on Accessible Leisure Tourism Experiences in Portugal. International Journal of Tourism Research, 14, 531-550.

Hajir, J., Obeidat, B., \& Al-dalahmeh, M. (2015). The Role of Knowledge Management Infrastructure in Enhancing Innovation at Mobile Telecommunication Companies in Jordan. European Journal of Social Sciences, 50(3), 313-330. 
Hamoud, M., Akour, M. A., \& Al-Salti, Z. (2016). Developing the Main Knowledge Management Process via Social Media in the IT Organisations: A Conceptual Perspective. International Journal of Business Administration, 7(5), 49-64.

Hassouna, M., Elyas, T., \& Abou Trab, M. S. (2015). Customer Churn in Mobile Markets: A Comparison of Techniques. International Business Research, 8(6), 224-237. https://doi.org/10.5539/ibr.v8n6p224

Hussian, A., Elyas, T., \& Nasseef, O. (2013). Research Paradigms: A Slippery Slope for Fresh Researchers. Life Science Journal, 10(4), 2374-2381.

Hunaiti, Z., Mansour, M., \& Al-Nawafleh. (2009). Electronic Commerce Adoption Barriers in Small and Medium-Sized Enterprises (SMEs) in Developing Countries: The Case of Libya. IBIMA Business Review, 2(5), 37-45.

Kanaan, R., \& Gharibeh, A. (2013). The Impact of Knowledge Sharing Enablers on Knowledge Sharing Capability: An Empirical Study on Jordanian Telecommunication Firms. European Scientific Journal, 9(22), 237-258.

Kateb, M., Swies, R., Obeidat, B., \& Maqableh, M. (2015). An Investigation on the Critical Factors of Information System Implementation in Jordanian Information Technology Companies. European Journal of Business and Management, 7(36), 11-28.

Kim, S., \& Lehto, Y. (2012). The Voice of Tourists with Mobility Disabilities Insights from Online Customer Complaint Websites. International Journal of Contemporary Hospitality Management, 24(3), 451-476.

Mahadeen, B., Al-Dmour, R., \& Obeidat, B. Y. (2016). Examining the effect of the Organization's Internal Control System on Organizational Effectiveness: A Jordanian empirical study. International Journal of Business Administration, 7(6), 22-41. https://doi.org/10.5430/ijba.v7n6p22

Maqableh, M., \& Karajeh, H. (2014a). Job Scheduling for Cloud Computing Using Neural Networks. Communications and Network, 6(3), 191. https://doi.org/10.4236/cn.2014.63021

Maqableh, M., \& Karajeh, H. (2014b). A Theoretical Perspective on the Relationship between Leadership Development, Knowledge Management Capability, and Firm Performance. Asian Social Science, 10(6), 128.

Masa'deh, R. (2013). The Impact of Information Technology Infrastructure Flexibility on Firm Performance: An Empirical Study of Jordanian Public Shareholding Firms. Jordan Journal of Business Administration, 204-224. https://doi.org/10.12816/0002054

Masa'deh, R., \& Kuk, G. (2009). Antecedents and Intermediaries between Strategic Alignment and Firm Performance. Conference of the Academy of Management Annual Meeting (AOM), Illinois, Chicago, USA.

Masa'deh, R., Gharaibeh, A., Maqableh, M., \& Karajeh, H. (2013a). An Empirical Study of Antecedents and Outcomes of Knowledge Sharing Capability in Jordanian Telecommunication Firms: A Structural Equation Modeling Approach. Life Science Journal, 10(4), 2284-2296.

Masa'deh, R., Hunaiti, Z., \& Bani Yaseen, A. (2008). An Integrative Model Linking IT-Business Strategic Alignment and Firm Performance: The Mediating Role of Pursuing Innovation and Knowledge Management Strategies. Communications of the International Business Information Management Association (IBIMA) Journal, 2(24), 180-187.

Masa'deh, R., Shannak, R., \& Maqableh, M. (2013b). A Structural Equation Modeling Approach for Determining Antecedents and Outcomes of Students' Attitude toward Mobile Commerce Adoption. Life Science Journal, $10(4), 2321-2333$.

Masa'deh, R., Tayeh, M., Al-Jarrah, I., \& Tarhini, A. (2015c). Accounting vs. Market-based Measures of Firm Performance Related to Information Technology Investments. International Review of Social Sciences and Humanities, 129-145.

Masa'deh, R. (2012). The Impact of Management Information Systems (MIS) on Quality Assurance (QA): A Case Study in Jordan. International Journal of Information, Business, and Management, 93-110.

Masa'deh, R., \& Shannak, R. (2012). Intermediary Effects of Knowledge Management Strategy and Learning Orientation on Strategic Alignment and Firm Performance. Research Journal of International Studies, 112-128.

Masa'deh, R., Gharaibeh, A., Tarhini, A., \& Obeidat, O. (2015a). Knowledge Sharing Capability: A Literature Review. In Fourth Scientific \& Research Conference on New Trends in Business, Management and Social Sciences, Istanbul, Turkey, 19-20 September 2015 (pp. 1-16). https://doi.org/10.2139/ssrn.2696924 
Masa'deh, R., Obeidat, B., \& Tarhini, A. (2016). A Jordanian Empirical Study of the Associations among Transformational Leadership, Transactional Leadership, Knowledge Sharing, Job Performance, and Firm Performance: A Structural Equation Modelling Approach. Journal of Management Development, 35(5), 681-705. https://doi.org/10.1108/JMD-09-2015-0134

Masa'deh, R., Obeidat, B., Al-Dmour, R., \& Tarhini, A. (2015b). Knowledge Management Strategies as Intermediary Variables between IT-Business Strategic Alignment and Firm Performance. European Scientific Journal, 11(7), 344-368.

Masa'deh, R., Shannak, R., Maqableh, M., \& Tarhini, A. (2017). The Impact of Knowledge Management on Job Performance in Higher Education: The Case of the University of Jordan. Journal of Enterprise Information Management, 30(2), 244-262. https://doi.org/10.1108/JEIM-09-2015-0087

McKercher, B., Packer, T. L., \& Yau, M. (2002). People with Disabilities and Tourism: An Investigation of Travel Strategies Tourism in Asia. Development, Marketing and Sustainability, 377-385.

Michopoulou, E., \& Buhalis, D. (2013). Information Provision or Challenging Markets: The Case of the Accessibility Requiring Market in the Context of Tourism. Information \& Management, 50, 229-239.

Michopoulou, E., Darcy, S., Ambrose, I., \& Buhalis, D. (2015). Accessible Tourism Futures: The World We Dream To Live In and The Opportunities We Hope To Have. Journal of Tourism Futures, 1(3), 179-188.

Mihaela, B. (2012). Tourism Industry in Romania and the Needs of People with Disabilities. Annals of the University of Oradea, Economic Science Series, 21(1), 481-486.

Nassar, B., \& Arzoky, M. (2015). An Empirical Analysis of the Seasonal Patterns in Aggregate Directors' Trades. International Journal of Economics and Finance, 7(9), 59-84. https://doi.org/10.5539/ijef.v7n9p59

Obeidat, B.Y., Tarhini, A., Masa'deh, R., \& Aqqad, N. (2017). The impact of intellectual capital on innovation via the mediating role of knowledge management: A structural equation modeling approach. International Journal of Knowledge Management Studies, 8(3), 15-33.

Obeidat, B. Y., Hashem, L., Alansari, I, \& Al-Salti, Z. (2016). The Effect of Knowledge Management Uses on Total Quality Management Practices: A Theoretical Perspective. Journal of Management and Strategy, 7(4), 18-29. https://doi.org/10.5430/jms.v7n4p18

Obeidat, B., Al-Suradi, M., \& Tarhini, A. (2016). The Impact of Knowledge Management on Innovation: An Empirical Study on Jordanian Consultancy Firms. Management Research Review, 39(10), 1214-1238.

Obeidat, B., El-Rimawi, S., Maqableh, M., \& Al-Jarrah, I. (2013). Evaluating the Profitability of the Islamic Banks in Jordan. European Journal of Economics, Finance and Administrative Sciences, 56, 27-36.

Obeidat, B., Sweis, R., Zyod, D., \& Alshurideh, M. (2012). The Effect of Perceived Service Quality on Customer Loyalty in Internet Service Providers in Jordan. Journal of Management Research, 4(4), 224-242.

Obeidat, B.Y., Al-Sarayrah, S., Al-Dmour, R. H., Al-Salti, Z., \& Sweis, R. (2016). Cultural Influence on Strategic Human Resource Management Practices: A Jordanian case study. International Business Research, 9(10), 94-114. https://doi.org/10.5539/ibr.v9n10p94

Obeidat, B.Y., Tarhini, A., \& Aqqad, N. (2017). The impact of intellectual capital on innovation via the mediating role of knowledge management: A structural equation modeling approach. International Journal of Knowledge Management Studies.

Orozco, J., Tarhini, A., Masa'deh, R., \& Tarhini, T. (2015). A framework of IS/business alignment management practices to improve the design of IT Governance architectures. International Journal of Business and Management, 10(4), 1-12. https://doi.org/10.5539/ijbm.v10n4p1

Ozturk, Y., Yayli, A., \& Yesiltas, M. (2008). Is The Turkish Tourism Industry Ready for a Disabled Customer's Market: The Views of Hotel and Travel Agency Managers. Tourism Management, 29, 382-389.

Packer, T., Mckercher, B., \& Yau, M. (2007). Understanding The Complex Interplay between Tourism, Disability and Environmental Contexts. Disability and Rehabilitation, 29(4), 281-292.

Pallant, J. (2005). SPSS Survival Manual: A Step Guide to Data Analysis Using SPSS for Windows Version 12. Chicago, Illinois: Open University Press.

Popiel, M. (2014). Paving the Way to Accessible Tourism on the Example of Krakow. European Journal of Tourism, Hospitality and Recreation, 55-71. 
Sang Yau, M., Mckercher, B., \& Packer, T. (2004). Traveling with a Disability More than an Access Issue. Annals of Tourism Research, 31(4), 946-960. https://doi.org/10.1016/j.annals.2004.03.007

Sanmargaraja, S., \& Ta Wee, S. (2013). Constraints of Alternative Tourism in Malaysia. International Journal of Advances in Management, Technology \& Engineering Sciences.

Sekaran, U., \& Bougie, R. (2013). Research Methods for Business: A Skill-Building Approach. (6th ed.). New York: Wiley.

Shannak, R., \& Akour, M. (2012). Knowledge Management Strategy Building: Literature Review. European Scientific Journal, 8(15), 143-168.

Shannak, R., Al-Zu'bi, Z., Obeidat, B., Alshurideh, M., \& Altamony, H. (2012a). A Theoretical Perspective on the Relationship between Knowledge Management Systems, Customer Knowledge Management, and Firm Competitive Advantage. European Journal of Social Sciences, 32(4), 520-532.

Shannak, R., Obeidat, B., \& Almajali, D. (2010). Information Technology Investments: A Literature Review. Proceedings of the 14th IBIMA Conference on Global Business Transformation through Innovation and Knowledge Management: An Academic Perspective, Istanbul-Turkey, 23rd-24th June, pp.1356-1368.

Shannak, R., Obeidat, B., \& Masa'deh, R. (2012b). Culture and the Implementation Process of Strategic Decisions in Jordan. Journal of Management Research, 4(4), 257-281. https://doi.org/10.5296/jmr.v4i4.2160

Small, J., \& Morgan, N. (2010). Tourism, Disability and Mobility, Tourism and Inequality: Problems and Prospects. UK. Cabi International, 1-13. Retrieved from https://www.researchgate.net/publication/235993202

Smith, R. (1987). Leisure of Disabled Tourists: Barriers to Participation. Annals of Tourism Research, 14(3), 376-389. https://doi.org/10.1016/0160-7383(87)90109-5

Tarhini, A., Al-Badi, A., Almajali, M., \& Alrabayaah, S. H. (2017). Factors influencing employees' Intention to use Cloud Computing. Journal of Management \& Strategy, 8(2), 47-62. https://doi.org/10.5430/jms.v8n2p47

Tarhini, A., El-Masri, M., Ali, M., \& Serrano, A. (2016). Extending the UTAUT model to understand the customers' acceptance and use of internet banking in Lebanon: A structural equation modeling approach. Information Technology and People, 29(4), 830-849. https://doi.org/10.1108/ITP-02-2014-0034

Tarhini, A., Mohammed, A., \& Maqableh, M. (2016). Modeling Factors Affecting Student's Usage Behaviour of E-Learning Systems in Lebanon. International Journal of Business and Management, 11(2), 299. https://doi.org/10.5539/ijbm.v11n2p299

Tarhini, A., Elyas, T., Akour, M. A., \& Al-Salti, Z. (2016). Technology, Demographic Characteristics and E-Learning Acceptance: A Conceptual Model Based on Extended Technology Acceptance Model. Higher Education Studies, 6(3), 72-89. https://doi.org/10.5539/hes.v6n3p72

Tarhini, A., Arachchilage, N., \& Abbasi, M. (2015). A Critical Review of Theories and Models of Technology Adoption and Acceptance in Information System Research. International Journal of Technology Diffusion, 6(4), 58-77. https://doi.org/10.4018/IJTD.2015100104

Tarhini, A., Mgbemena, C., AbouTrab, M.S., \& Masa'deh, R. (2015). User Adoption of Online Banking in Nigeria: A Qualitative study. Journal of Internet Banking and Commerce, 20(3), 1-8.

Vos, S., Vzw, T., Belgium, Ambrose, I., \& Eworx, S.A. (2007). Services and Facilities for Accessible Tourism in Europe, ENAT, VS/2005/0675. Retrieved from http://www.accessibletourism.org/?i=enat.en.reports

Vratskikh, I., Al-Lozi, M., \& Maqableh, M. (2016). The Impact of Emotional Intelligence on Job Performance via the Mediating Role of Job Satisfaction. International Journal of Business and Management, 69-91. https://doi.org/10.5539/ijbm.v11n2p69

World Tourism Organization (UNWTO) (2013). Recommendations on Accessible Tourism. Retrieved from http://ethics.unwto.org/en/content/accessible-tourism

Yuhua, B. (2006). Accessibility and Attitudinal Barriers Encountered By Travelers with Physical Disabilities in China. University of Missouri-Columbia.

Zhang, Y., \& Tian Cole, S. (2016). Dimensions of Lodging Guest Satisfaction among Guests with Mobility Challenges: A Mixed-Method Analysis of Web-Based Texts. Tourism Management, 53, 13-27. https://doi.org/10.1016/j.tourman.2015.09.001 